\title{
KAJIAN OPTIMASI ENERGI PADA PEMBANGKIT LISTRIK TENAGA MIKROHIDRO KANZY I DI KABUPATEN PASURUAN
}

\author{
Riska Karunia Ellanda ${ }^{1}$, Pitojo Tri Juwono ${ }^{2}$, Runi Asmaranto ${ }^{2}$ \\ ${ }^{1}$ Staf Sungai Wilayah Timur Kementrian Pekerjaan Umum dan Perumahan Rakyat \\ ${ }^{2}$ Dosen Magister Teknik Pengairan Jurusan Manajemen Sumber Daya Air Universitas Brawijaya \\ email : riskaellanda87@gmail.com
}

\begin{abstract}
ABSTRAK : Keterbatasan jumlah pembangkit ternyata tidak dapat mengimbangi pertumbuhan industri maupun tingkat sosial ekonomi masyarakat. Dalam rangka mewujudkan ketahanan energi nasional dan menurunkan tingkat karbondioksida $\left(\mathrm{CO}_{2}\right)$, pemanfaatan sumber energi baru terbaharukan untuk kepentingan ketenagalistrikan naisonal harus diutamakan.

Dalam studi optimasi PLTMH Kanzy I ini bertujuan untuk melihat bagaimana debit aliran di tahun kering, normal dan basah sehingga potensi daya disetiap kondisi dapat terlihat. Pada PLTMH Kanzy I memakai aliran Sungai Welang dengan menggunakan debit andalan $\mathrm{Q}_{32}$ pada tahun basah (tahun 2010) sebesar $22,75 \mathrm{~m}^{3} / \mathrm{dt}$ dan energi tahunan yang dihasilkan sebesar 21.681.469,97 kWh. Pada debit andalan $\mathrm{Q}_{56}$ pada tahun normal (tahun 1987) sebesar $4,63 \mathrm{~m}^{3} / \mathrm{dt}$ dan energi tahunan yang dihasilkan sebesar 8.167.878,92 kWh. Dan pada debit andalan $\mathrm{Q}_{80}$ pada tahun kering (tahun 2007) sebesar 0,022 $\mathrm{m}^{3} / \mathrm{dt}$ dan energi tahunan yang dihasilkan sebesar 59.211,41 kWh.
\end{abstract}

Kata kunci : Pembangkit listrik tenaga mikrohidro, optimasi energi, debit andalan, tinggi jatuh.

ABSTRACT: The limited number of micro hydro power plant can not fulfill with the industry growth and socio-economic level of the community. In order to realize national energy security and reduce the level of carbon dioxide (CO2), the utilization of renewable energy sources for the sake of electric power should be prioritized.

This study aims to see the discharge in dry, normal and wet season so that the potential power in every condition can be seen. PLTMH Kanzy I uses the dependable discharge of $Q_{32}$ in wet year (2010) is $22.75 \mathrm{~m} 3 / \mathrm{sec}$ and the annual energy produced is $21.681 .469,97 \mathrm{kWh}$. At the $Q_{56}$ dependable discharge in the normal year (year 1987) of $4.63 \mathrm{~m} 3 / \mathrm{sec}$ and the annual energy generated amounted to $8,167,878.92 \mathrm{kWh}$. And at the dependable discharge of $Q_{80}$ in dry year (in 2007) amounted to 0.022 $\mathrm{m} 3 / \mathrm{sec}$ and the annual energy generated amounted to 59,211.41 $\mathrm{kWh}$.

Keywords: micro hydro power plant, energy optimization, dependable discharge, net hea

Kebutuhan listrik dewasa ini akan terus meningkat seiring dengan membaiknya kondisi perekonomian, pertambahan jumlah penduduk, dan peningkatan pembangunan. Dan infrastruktur merupakan salah satu prasyarat utama yang harus dibangun seiring dengan pembangunan itu sendiri. Keterbatasan jumlah pembangkit ternyata tidak dapat mengimbangi pertumbuhan industri maupun tingkat sosial ekonomi masyarakat. Sedangkan infrastruktur ini merupakan salah satu prasyarat utama investasi yang sekarang ini tengah digalakkan oleh pemerintah (Anonim, 2014). Di sisi lain pemenuhan pembangunan tenaga listrik untuk masyarakat umum terutama di pedesaan masih cukup rendah. Upaya pemecahan dari permasalahan tersebut adalah pembangunan listrik pedesaan untuk memenuhi kebutuhan 
listrik bagi masyarakat di pedesaan yang besumber dari Perusahaan Listrik Negara (PLN) maupun sumber lainya.

Dalam rangka mewujudkan ketahanan energi nasional dan menurunkan tingkat karbondioksida $\left(\mathrm{CO}_{2}\right)$, pemanfaatan sumber energi baru terbaharukan untuk kepentingan ketenagalistrikan naisonal harus diutamakan. Pemerintah membuat program peningkatan pembangunan pembangkit listrik alternatif non minyak antara lain dengan memanfaatkan potensi sumberdaya alam berupa air sungai yang banyak terdapat di seluruh Indonesia. Kondisi melimpahnya potensi sumber daya energi terbarukan khususnya tenaga air merupakan peluang besar dan sekaligus sebagai tantangan untuk mengembangkan pembangkit-pembangkit listrik skala kecil bagi masyarakat pedesaan. Untuk maksud tersebut diupayakan pembangunan pembangkit listrik tenaga air oleh pihak swasta. Tenaga listrik yang dihasilkan dari pembangkit yang dibangun oleh pihak swasta nantinya akan dimanfaatkan oleh PT. PLN (Persero) guna memenuhi kebutuhan tenaga didaerah setempat melalui suatu perjanjian jual beli tenaga listrik - PPA (Power Purchase Agreement)- antara PT. PLN (Persero) dengan pihak swasta tersebut.

Salah satu solusi menghadapi masalah kelistrikan terutama di daerah perdesaan adalah pembangkit listrik tenaga air skala mikro. Pembangkit Listrik Tenaga Mikrohidro (PLTMH) merupakan sejenis pembangkit tenaga listrik yang mirip dengan PLTA hanya skalanya lebih kecil. Air dari sungai menggerakan pemutar kincir secara alami dan disambung ke generator untuk menghasilkan listrik.

Teknlogi pembangkit listrik tenaga mikrohidro (PLTMH) merupakan teknologi yang paling matang untuk dikembangkan didaerah pedesaan yang jauh dari jangkauan jaringan listrik. Sumber energi listrik dengan mikrohidro termasuk bersih serta ramah lingkungan.

Keanekaragaman teknologi pembangkit listrik tenaga mikrohidro memungkinkan diintegrasikan dengan jaringan yang ada dan dapat didistribusikan ke daerah terpencil dan dapat dimanfaatkan secara komersial dalam skala kecil untuk dapat mendorong terciptanya aktivitas pembangunan yang dapat meningkatkan taraf hidup masyrakat di pedesaan.
Saat ini Menteri Energi dan Sumber Daya Mineral telah mengeluarkan Keputusan tentang pemanfaatan sumber energi terbarukan untuk penyediaan tenaga listrik No. 12 Tahun 2017. Kebijakan tersebut memungkinkan pembangunan pembangkit listrik tenaga mikrohidro (PLTMH) dan sumber energi baru terbarukan lainya terintegrasi (terkoneksi) dengan jaringan listrik Perusahaan Litrik Negara (PLN) dalam bentuk usaha penjualan tenaga listrik. Maka dengan demikian, pembangkit listrik tenaga mikrohidro (PLTMH) tidak hanya berada pada ruang lingkup pembangunan daerah terpencil tetapi juga telah menjadi peluang investasi pada daerah yang memiliki infrastruktur sistem Perusahaan Listrik Negara (PLN).

Melihat potensi yang dimiliki oleh pembangkit listrik tenaga mikrohidro (PLTMH) Kanzy 1 serta meningkatnya kebutuhan masyarakat akan kebutuhan listrik maka usaha pengoptimalan energi dalam pembangunan pembangit listrik tenaga mikrohidro (PLTMH) Kanzy 1 sangat penting dilakukan. Oleh karena itu kegiatan kajian optimasi energi pembangkit listri tenaga mikrohidro Kanzy 1 sangat diperlukan mengingat banyak faktor yang harus diperhatikan dalam pembangunan pembangkit listrik tenaga mikrohidro (PLTMH) untuk penyediaan listrik pedesaan agar pembangunan tersebut dapat memberikan manfaat secara optimal dan berkelajutan serta dapat memberikan keuntungan kepada pihak investor.

Dalam studi optimasi PLTMH Kanzy I ini bertujuan untuk melihat bagaimana debit aliran di tahun kering, normal dan basah sehingga potensi daya disetiap kondisi dapat terlihat.

\section{BAHAN DAN METODE}

Pembangkit listrik tenaga mikrohidro (PLTM ) Kanzy 1 berada pada aliran Sungai Welang yang terletak di Desa Cowek, Kecamatan Purwodadi, Kabupaten Pasuruan, Provinsi Jawa Timur. Secara geografis Kecamatan Purwodadi terletak pada $07^{\circ}-08^{\circ} 30^{\prime}$ LS dan $112^{\circ}-113^{\circ} 30^{\circ}$ BT.

Tahapan pengerjaan kajian ini adalah sebagai berikut :

1. Menentukan besarnya debit rencana optimasi berdasarkan keandalanya dengan menggunakan metode F.J. Mock. 
2. Menghitung tinggi jatuh efektif

3. Menentukan pemilihan jenis turbin yang berhubungan erat dengan tinggi jatuh dan debit rencana.

4. Melakukan simulasi energi tahunan dengan memperhitungkan :

$>$ Debit sungai dari FDC pada tahun basah, tahun kering, dan tahun normal

$>$ Efisiensi turbin dan efisiensi generator

$>$ Jika debit sungai > debit rencana maka yang di pakai dalam simulasi adalah debit rencana

$>$ Jika debit sungai < debit rencana turbin maka yang di pakai dalam simulasi adalah debit sungai

$>$ Jika debit sungai < debit minimum turbin maka turbin mati

$>$ Melakukan perhitungan energi

$>\quad$ Menentukan annual energy

5. Menghitung plant factor, jika plant factor $\leq$ $65 \%$ maka kembali ke pemilihan debit.

\section{Debit Andalan}

Menurut Soemarto (1999), Debit andalam merupakan debit yang tersedia guna keperluan tertentu contohnya untuk keperluan PLTA, Irigasi, Air baku dan lain lain sepanjang tahun, dengan resiko kegagalan yang telah diperhitungkan. Dalam perencanaan suatu pembangkit listrik tenaga mikrohidro (PLTMH), debit perencanaan menggunakan debit andalan (dependable discharge). Hal terebut dimaksudkan guna menentukan debit yang diharapkan tersedia di sungai untuk memperkirakan besarnya kapasitas terpasang. Besarnya debit andalan yang diambil untuk menyelesaikan optimum penggunaan air di beberapa macam pekerjaan di bidang pengairan adalah sebagai berikut :

1. Penyediaan Air Minum $99 \%$

2. Penyediaan Industri $95 \%-98 \%$

3. Penyediaan Irigasi $70 \%-95 \%$

4. Pembangkit Listrik Tenaga Air $85 \%$ $90 \%$

\section{Kurva Durasi Aliran}

Lengkung durasi aliran (flow duration curve) merupakan suatu grafik yang memperlihatkan debit sungai dan selama beberapa waktu tertentu dalam satu tahun. Pada gambar 1, jelas bahwa debit minimum terdapat selama satu tahun penuh., sedangkan debit maksimum hanya terdapat selama beberapa jam. Lengkung durasi aliran digambarkan dari data data debit, sekurang - kurangnya selama 10 tahun.

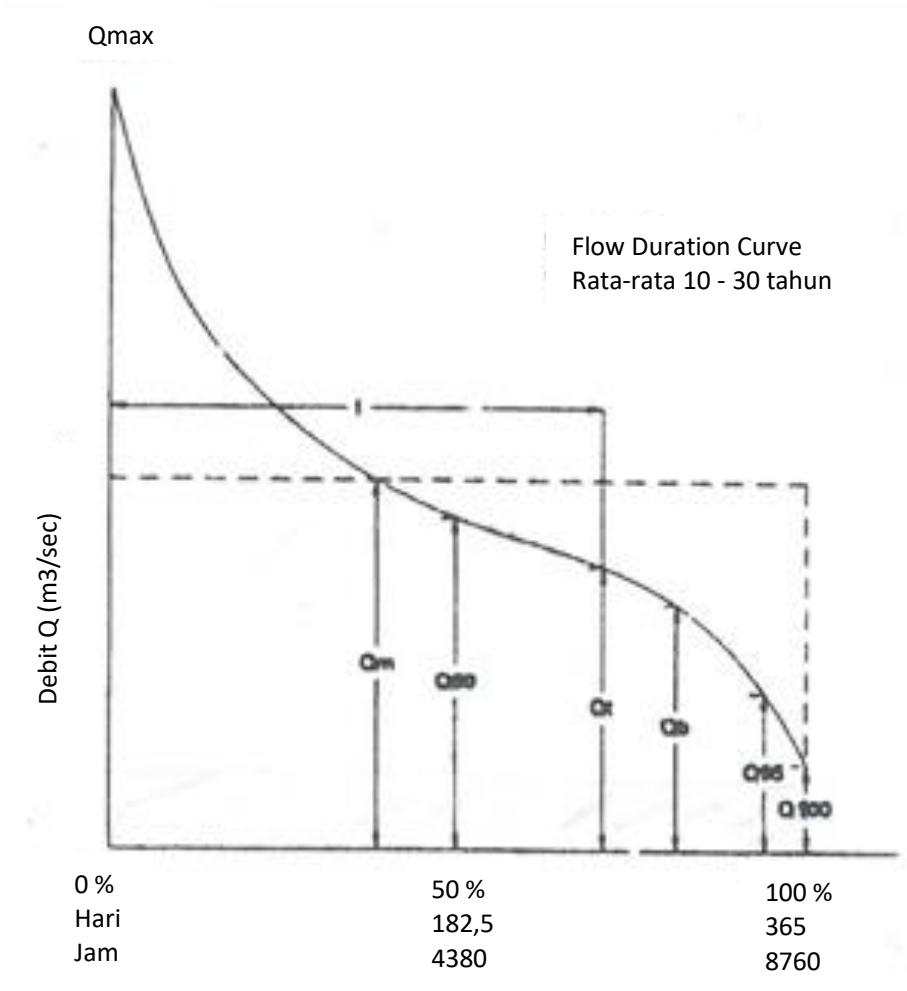

Gambar 1 Lengkung Durasi Aliran (Flow Duration Curve)

\section{Tinggi Jatuh Efektif}

Tinggi jatuh efektif adalah tinggi jatuh dari permukaan air waduk dititik penyadapan dan permukaan air di saluran bawah (tail race) setelah dipergunakan untuk menghasilkan daya dikurangi dengan total kehilangan tinggi tekan akibat saringan, pemasukan, belokan, gesekan dan lain - lain (linsey, 1985:162).

Persamaan tinggi jatuh efektif adalah sebagai berikut :

$\mathrm{H}_{\mathrm{eff}}=\mathrm{E}_{\mathrm{MAW}}-\mathrm{TWL}-\mathrm{hl}$

dimana :

$\mathrm{H}_{\text {eff }} \quad=$ Tinggi jatuh efektif (m)

$\mathrm{E}_{\mathrm{MAW}}=$ Elevasi muka air waduk $(\mathrm{m})$

TWL = Tail Water Level / elevasi muka air di saluran bawah $(\mathrm{m})$

hl = Total kehilangan tinggi tekan $(\mathrm{m})$ 


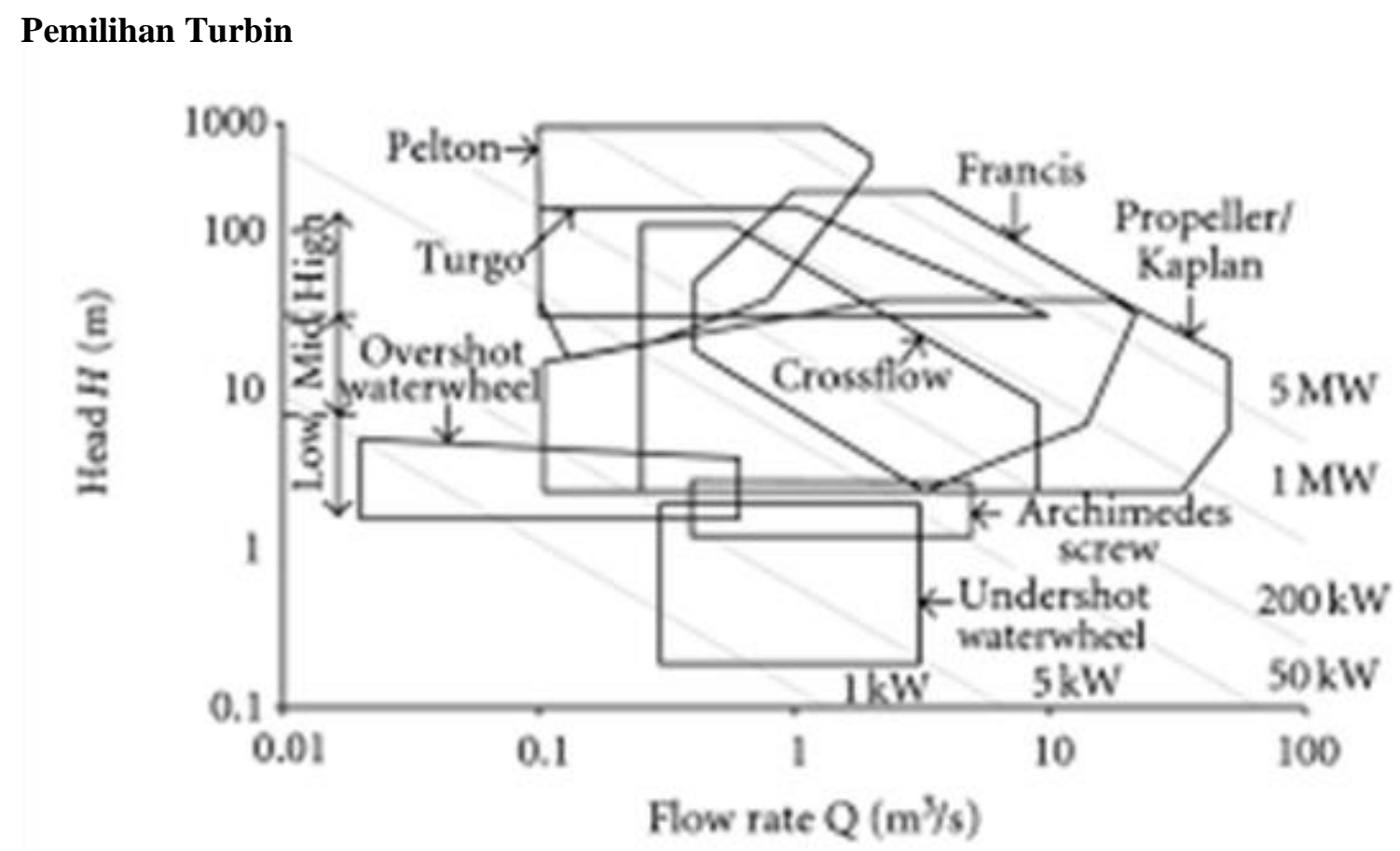

\section{Gambar 2 Diagram Aplikasi berbagai Jenis Turbin (Head Vs Flow rate)}

Turbin - turbin hidrolik, berhubungan erat dengan generator, fungsi utamanya adalah mengubah energi air menjadi energi listrik (Dandekar, 1991). Air yang mengalir melalui turbin pada penggerak (runner) dan turbin dan membuatnya berputar (energi mekanis). Energi mekanis diubah dengan generator listrik menjadi tenaga listrik.

Adapun tipe penggunaan head yang berlaku pada beberapa macam turbin diantaranya:

Kaplan : $2<\mathrm{H}<40$

Francis : $10<\mathrm{H}<350$

Pelton : $50<\mathrm{H}<\mathrm{H}<100$

Turgo : $50<\mathrm{H}<250$

Kecepatan spesifik setiap turbin memiliki kisaran, antara lain sebagai berikut:

- Turbin pelton $12<\mathrm{Ns}<25$

- Turbin francis $60<\mathrm{Ns}<300$

- Turbin crossflow $40<\mathrm{Ns}<200$

- Turbin propeller $250<\mathrm{Ns}<1000$

Dengan mengetahui Ns turbin maka perencanaan dan pemilihan jenis turbin akan lebih mudah. Untuk estimasi perhitungan dapat dilakukan dengan menggunakan rumus berikut:
$\mathrm{N}=2145 \mathrm{P} \mathrm{Ns} \times \mathrm{H}$

dengan:

$\mathrm{N} \quad=$ kecepatan pada turbin (rpm)

Ns $\quad=$ kecepatan spesifik $(\mathrm{rpm})$

$\mathrm{h} \quad=$ tinggi jatuh efektif $(\mathrm{m})$

$\mathrm{P} \quad$ = daya yang dihasilkan $(\mathrm{kW})$

\section{Perhitungan Daya dan Energi}

Daya Teoritis $=9,81 \times Q \times H_{e f f}$

dengan:

$\eta_{t}=$ efisiensi turbin

$\eta g=$ efisiensi generator

$Q=$ debit pembangkit $\left(\mathrm{m}^{3} / \mathrm{dt}\right)$

$H_{\text {eff }}=$ tinggi jatuh efektif $(\mathrm{m})$

Perhitungan banyaknya energi yang dihasilkan pembangkit dalam satu tahun menggunakan persamaan berikut: 
$E=P \times 24 \times n$

Dengan :

$$
\begin{array}{ll}
P & =\text { daya }(\mathrm{kW}) \\
n & =\text { jumlah hari }
\end{array}
$$

\section{HASIL DAN PEMBAHASAN}

\section{Debit Andalan}

Guna mendapatkan kapasitas PLTMH, tidak terlepas dari perhitungan berapa banyak air yang dapat diandalkan untuk membangkitkan PLTMH. Debit andalan adalah debit yang masih dimungkinkan untuk keamanan operasional suatu bangunan air, dalam hal ini adalah
PLTMH. hasil rekapitulasi disajikan dalam tabel 2 dan grafik 2.

Debit yang digunakan untuk perhitungan desain PLTMH adalah debit terpilih pada tahun basah adalah $2010\left(\mathrm{Q}_{32}\right)$, tahun normal 1989 $\left(\mathrm{Q}_{56}\right)$ dan tahun kering $2007\left(\mathrm{Q}_{80}\right)$.

Debit rencana pada tahun basah dapat dipilih dengan cara mengurutkan debit pada tahun basah dari mulai debit terbesar sampai dengan debit terkecil, sehingga didapatkan peluang terjadinya debit selama satu tahun. Pada Tabel 1 dipilih debit dengan peluang terjadi 32 $\%$ sesuai dengan (Anonim, 2007) sebesar 22,75 $\mathrm{m}^{3} / \mathrm{dt}$ yang digunakan untuk $\mathrm{Q}$ rencana pada tahun basah.

Tabel 1 Debit tahun 2010 (Tahun Basah)

\begin{tabular}{|c|c|c|c|c|c|}
\hline No & Bulan & Periode & $\begin{array}{c}\text { Debit } \\
\left(\mathbf{m}^{\mathbf{3}} / \mathbf{d t}\right)\end{array}$ & $\begin{array}{c}\text { Debit Terurut } \\
\left(\mathbf{m}^{\mathbf{3}} / \mathbf{d t}\right)\end{array}$ & $\begin{array}{c}\text { Peluang } \\
(\mathbf{\%})\end{array}$ \\
\hline 1 & Januari & I & 27.68 & 28.75 & 4.00 \\
\hline 2 & Januari & II & 23.53 & 27.68 & 8.00 \\
\hline 3 & Februari & I & 20.42 & 27.39 & 12.00 \\
\hline 4 & Februari & II & 22.75 & 27.09 & 16.00 \\
\hline 5 & Maret & I & 28.75 & 25.35 & 20.00 \\
\hline 6 & Maret & II & 15.32 & 24.64 & 24.00 \\
\hline 7 & April & I & 19.44 & 23.53 & 28.00 \\
\hline 8 & April & II & 27.39 & 22.75 & 32.00 \\
\hline 9 & Mei & I & 27.09 & 20.42 & 36.00 \\
\hline 10 & Mei & II & 16.38 & 19.44 & 40.00 \\
\hline 11 & Juni & I & 18.58 & 18.58 & 44.00 \\
\hline 12 & Juni & II & 4.81 & 16.81 & 48.00 \\
\hline 13 & Juli & I & 10.03 & 16.38 & 52.00 \\
\hline 14 & Juli & II & 4.10 & 15.32 & 56.00 \\
\hline 15 & Agustus & I & 1.84 & 13.55 & 60.00 \\
\hline 16 & Agustus & II & 7.61 & 11.30 & 64.00 \\
\hline 17 & September & I & 5.70 & 10.91 & 68.00 \\
\hline 18 & September & II & 10.91 & 10.03 & 72.00 \\
\hline 19 & Oktober & I & 11.30 & 7.61 & 76.00 \\
\hline 20 & Oktober & II & 13.55 & 7.45 & 80.00 \\
\hline 21 & November & I & 25.35 & 5.70 & 84.00 \\
\hline 22 & November & II & 16.81 & 4.81 & 88.00 \\
\hline 23 & Desember & I & 24.64 & 4.10 & 92.00 \\
\hline 24 & Desember & II & 7.45 & 1.84 & 96.00 \\
\hline
\end{tabular}

Sumber : Hasil Perhitungan

Debit rencana pada tahun basah dapat dipilih dengan cara mengurutkan debit pada tahun basah dari mulai debit terbesar sampai dengan debit terkecil, sehingga didapatkan peluang terjadinya debit selama satu tahun. Pada
Tabel 1 dipilih debit dengan peluang terjadi 32 $\%$ sesuai dengan (Anonim, 2007) sebesar 22,75 $\mathrm{m}^{3} / \mathrm{dt}$ yang digunakan untuk $\mathrm{Q}$ rencana pada tahun basah. 
Tabel 2 Debit tahun 1989 (Tahun Normal)

\begin{tabular}{|c|c|c|c|c|c|}
\hline No & Bulan & Periode & $\begin{array}{c}\text { Debit } \\
\left(\mathbf{m}^{\mathbf{3}} / \mathbf{d t}\right)\end{array}$ & $\begin{array}{c}\text { Debit Terurut } \\
\left(\mathbf{m}^{\mathbf{3}} / \mathbf{d t}\right)\end{array}$ & $\begin{array}{c}\text { Peluang } \\
(\mathbf{\%})\end{array}$ \\
\hline 1 & Januari & I & 9.50 & 21.37 & 4.00 \\
\hline 2 & Januari & II & 16.47 & 16.47 & 8.00 \\
\hline 3 & Februari & I & 14.19 & 14.19 & 12.00 \\
\hline 4 & Februari & II & 8.04 & 11.64 & 16.00 \\
\hline 5 & Maret & I & 6.13 & 10.72 & 20.00 \\
\hline 6 & Maret & II & 11.64 & 10.40 & 24.00 \\
\hline 7 & April & I & 4.38 & 9.50 & 28.00 \\
\hline 8 & April & II & 5.14 & 9.38 & 32.00 \\
\hline 9 & Mei & I & 5.26 & 8.04 & 36.00 \\
\hline 10 & Mei & II & 9.38 & 6.13 & 40.00 \\
\hline 11 & Juni & I & 10.72 & 5.68 & 44.00 \\
\hline 12 & Juni & II & 4.63 & 5.26 & 48.00 \\
\hline 13 & Juli & I & 3.25 & 5.14 & 52.00 \\
\hline 14 & Juli & II & 3.51 & 4.63 & 56.00 \\
\hline 15 & Agustus & I & 0.97 & 4.38 & 60.00 \\
\hline 16 & Agustus & II & 0.63 & 3.51 & 64.00 \\
\hline 17 & September & I & 0.39 & 3.25 & 68.00 \\
\hline 18 & September & II & 0.24 & 0.97 & 72.00 \\
\hline 19 & Oktober & I & 0.13 & 0.63 & 76.00 \\
\hline 20 & Oktober & II & 0.45 & 0.45 & 80.00 \\
\hline 21 & November & I & 0.10 & 0.39 & 84.00 \\
\hline 22 & November & II & 10.40 & 0.24 & 88.00 \\
\hline 23 & Desember & I & 5.68 & 0.13 & 92.00 \\
\hline 24 & Desember & II & 21.37 & 0.10 & 96.00 \\
\hline
\end{tabular}

Sumber : Hasil Perhitungan

Debit rencana pada tahun normal dapat dipilih dengan cara mengurutkan debit pada tahun normal dari mulai debit terbesar sampai dengan debit terkecil, sehingga didapatkan peluang terjadinya debit selama satu tahun. Dari perhitungan pada Tabel 2 didapatkan debit dengan peluang $56 \%$ (Anonim, 2007) sebesar $4,63 \mathrm{~m}^{3} / \mathrm{dt}$ yang dugunakan sebagai $\mathrm{Q}$ rencana pada tahun normal.

Tabel 3 Debit tahun 2007 (Tahun Kering)

\begin{tabular}{|c|c|c|c|c|c|}
\hline No & Bulan & Periode & $\begin{array}{c}\text { Debit } \\
\left(\mathbf{m}^{\mathbf{3}} / \mathbf{d t}\right)\end{array}$ & $\begin{array}{c}\text { Debit Terurut } \\
\left(\mathbf{m}^{\mathbf{3}} / \mathbf{d t}\right)\end{array}$ & $\begin{array}{c}\text { Peluang } \\
(\mathbf{\%})\end{array}$ \\
\hline 1 & Januari & I & 7.12 & 13.73 & 4.00 \\
\hline 2 & Januari & II & 0.83 & 9.40 & 8.00 \\
\hline 3 & Februari & I & 3.60 & 8.16 & 12.00 \\
\hline 4 & Februari & II & 9.40 & 7.64 & 16.00 \\
\hline 5 & Maret & I & 4.74 & 7.12 & 20.00 \\
\hline 6 & Maret & II & 13.73 & 4.99 & 24.00 \\
\hline 7 & April & I & 8.16 & 4.74 & 28.00 \\
\hline 8 & April & II & 7.64 & 3.60 & 32.00 \\
\hline 9 & Mei & I & 2.02 & 2.61 & 36.00 \\
\hline 10 & Mei & II & 1.15 & 2.02 & 40.00 \\
\hline 11 & Juni & I & 2.61 & 1.15 & 44.00 \\
\hline 12 & Juni & II & 0.69 & 0.83 & 48.00 \\
\hline 13 & Juli & I & 0.42 & 0.69 & 52.00 \\
\hline 14 & Juli & II & 0.24 & 0.42 & 56.00 \\
\hline 15 & Agustus & I & 0.16 & 0.24 & 60.00 \\
\hline 16 & Agustus & II & 0.09 & 0.16 & 64.00 \\
\hline 17 & September & I & 0.06 & 0.09 & 68.00 \\
\hline 18 & September & II & 0.04 & 0.06 & 72.00 \\
\hline 19 & Oktober & I & 0.02 & 0.04 & 76.00 \\
\hline 20 & Oktober & II & 0.01 & 0.02 & 80.00 \\
\hline 21 & November & I & 0.01 & 0.01 & 84.00 \\
\hline 22 & November & II & 0.00 & 0.01 & 88.00 \\
\hline 23 & Desember & I & 0.00 & 0.00 & 92.00 \\
\hline 24 & Desember & II & 4.99 & 0.00 & 96.00 \\
\hline
\end{tabular}

Sumber : Hasil Perhitungan 
Debit rencana pada tahun normal dapat dipilih dengan cara mengurutkan debit pada tahun normal dari mulai debit terbesar sampai dengan debit terkecil, sehingga didapatkan peluang terjadinya debit selama satu tahun. Dari perhitungan pada Tabel 3 didapatkan debit dengan peluang $80 \%$ (Anonim, 2007) sebesar $0,02 \mathrm{~m}^{3} / \mathrm{dt}$ yang digunakan sebagai $\mathrm{Q}$ rencana pada tahun kering.

\section{Pipa Pesat}

Pipa pesat merupakan pipa yang direncanakan untuk dapat menahan tekanan tinggi dan berfungsi untuk mengalirkan air dari kolam penampungan menuju turbin. Pipa pesat direncanakan dengan menggunakan pipa Galvanized Iron (GI).

- Diameter Pipa Pesat

Pada $\mathrm{Q}_{32}=2,74 \mathrm{~m}$

Pada $\mathrm{Q}_{56}=1,44 \mathrm{~m}$

Pada $\mathrm{Q}_{80}=0,13 \mathrm{~m}$

- Tebal Pipa Pesat

Pada $\mathrm{Q}_{32}=97,68 \mathrm{~mm}$

Pada $\mathrm{Q}_{56}=51,31 \mathrm{~mm}$

Pada $\mathrm{Q}_{80}=6,29 \mathrm{~mm}$

- Kehilangan Tinggi Tekan

Kehilangan tinggi tekan aliran adalah menurunnya besaran energi akibat gesekan maupun kontraksi yang terjadi selama proses pengaliran. Perhitungan head loss dibutuhkan untuk mengetahui tinggi jatuh efektif pada PLTMH.

Kehilangan Tinggi Tekan Total

$$
\begin{aligned}
& \text { Pada } \mathrm{Q}_{32} \\
& \begin{aligned}
\mathrm{K} & =\mathrm{K} 1+\mathrm{K} 2+\mathrm{K} 3+\mathrm{K} 4+\mathrm{K} 5+\mathrm{K} 6 \\
& =0,484+0,56+0,50+0,2+0,44+0,7 \\
& =1,979
\end{aligned}
\end{aligned}
$$

$$
\begin{aligned}
& \text { Pada } \mathrm{Q}_{56} \\
& \begin{aligned}
\mathrm{K} & =\mathrm{K} 1+\mathrm{K} 2+\mathrm{K} 3+\mathrm{K} 4+\mathrm{K} 5+\mathrm{K} 6 \\
& =0,484+0,56+0,50+0,2+0,44+1,6 \\
& =2,7
\end{aligned}
\end{aligned}
$$

$$
\begin{aligned}
& \text { Pada } \mathrm{Q}_{80} \\
& \begin{aligned}
\mathrm{K} & =\mathrm{K} 1+\mathrm{K} 2+\mathrm{K} 3+\mathrm{K} 4+\mathrm{K} 5+\mathrm{K} 6 \\
& =0,484+0,56+0,50+0,2+0,44+32,8 \\
& =34
\end{aligned}
\end{aligned}
$$

K1 merupakan kehilangan tinggi akibat saringan (trash rack), K2 Kehilangan tinggi tekan akibat pemasukan pada pipa , K3 Koefisien kehilangan tinggi tekan pada mulut pipa dengan tepi siku - siku (Linsey, 1985:311), K4 Kehilangan tinggi akibat Katup, K5 Kehilangan tinggi akibat belokan sebanyak 2 kali dengan sudut 45, K6 merupakan Kehilangan tinggi akibat gesekan pada pipa.

Selanjutnya setiap tahun digambarkan pada grafik seperti tampak pada Gambar 3 dari tahun 1986 sampai 2015 (30 tahun), maka dapat kita tentukan tahun mana yang termasuk tahun basah, tahun cukup dan tahun kering. Pada Sungai Welang hasilnya adalah sebagai berikut :

1. Tahun basah adalah tahun 2010 digunakan untuk dasar perhitungan debit andalan $\left(\mathrm{Q}_{32}\right)$ sebesar $22,75 \mathrm{~m}^{3} / \mathrm{dt}$.

2. Tahun cukup adalah tahun 1989 digunakan untuk dasar perhitungan debit andalan $\left(\mathrm{Q}_{56}\right)$ sebesar $4,63 \mathrm{~m}^{3} / \mathrm{dt}$.

3. Tahun Kering adalah tahun 2007 digunakan untuk dasar perhitungan debit andalan $\left(\mathrm{Q}_{80}\right)$ sebesar $0,022 \mathrm{~m}^{3} / \mathrm{dt}$.

\section{Tinggi Jatuh Efektif}

Elevasi muka air bak penenang $=295,06 \mathrm{~m}$

TWL $=244,26 \mathrm{~m}$

Kehilangan tinggi tekan total $=1,266 \mathrm{~m}$

Maka :

Pada $\mathrm{Q}_{32}$

$\mathrm{H}_{\text {eff }}=\mathrm{El}$ muka air bak penenang $-\mathrm{El}$ TWL $\mathrm{hl}_{\text {total }}$

$=295,06-244,26-1,266$

$=49,529 \mathrm{~m}$

Pada $\mathrm{Q}_{56}$

$\mathrm{H}_{\text {ef } \mathrm{f}}=\mathrm{El}$ muka air bak penenang $-\mathrm{El}$ TWL $\mathrm{hl}_{\text {total }}$ $=295,06-244,26-1,415$

$=49,385 \mathrm{~m}$

Pada $\mathrm{Q}_{80}$

$\mathrm{H}_{\text {eff }}=\mathrm{El}$ muka air bak penenang - El TWL -

$\mathrm{hl}_{\text {total }}$

$=295,06-244,26-0,016$

$=50,784 \mathrm{~m}$ 


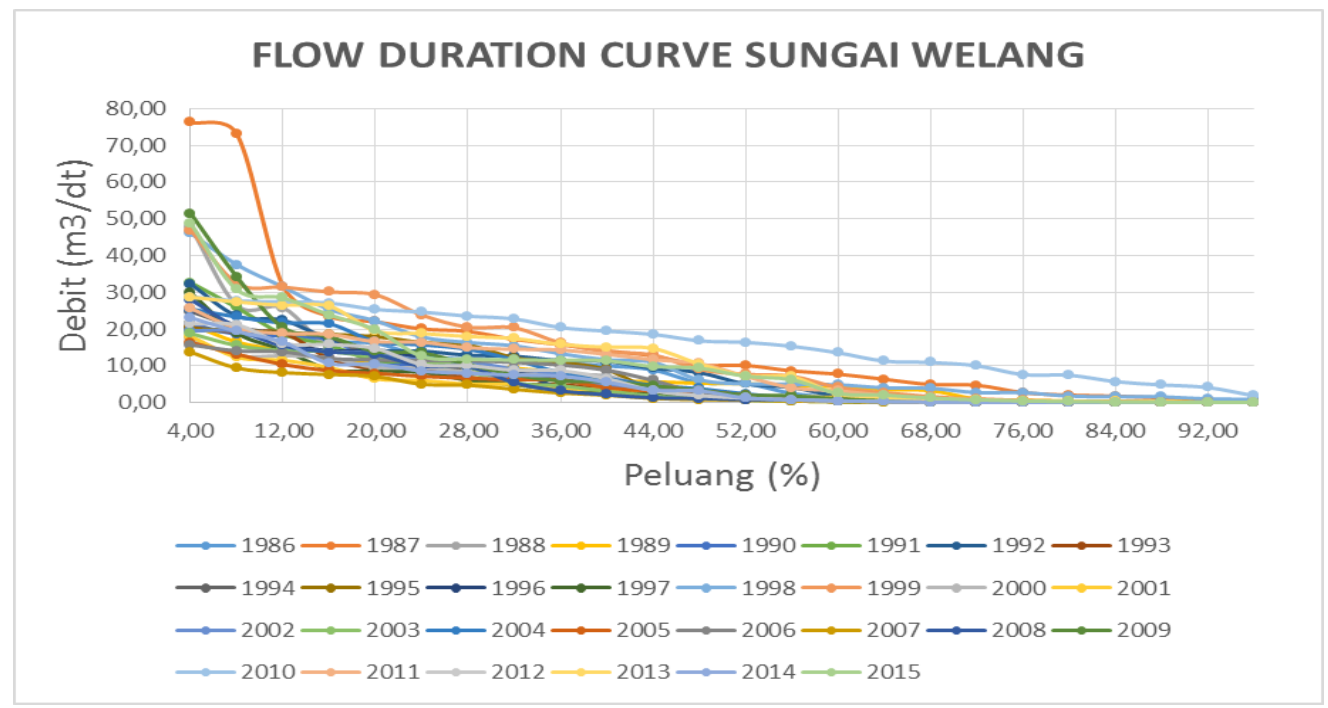

Gambar 3 Kurva Durasi aliran Sungai Welang

\section{Perhitungan Daya dan Energi}

$\mathrm{P}=\eta \times 9,81 \times \mathrm{H}_{\mathrm{eff}} \times \mathrm{Q}$

$\mathrm{E}=\mathrm{P} \times \mathrm{t} \times \mathrm{n}$

Pada Tabel 4 perhitungan daya dan energi masing masing keandalan menghasilkan energi tahunan sesuai dengan kapasitas terpasang. dalam setiap keandalan memiliki beberapa alternatif kapasitas terpasang sesuai dengan energi teoritis yang dihasilkan.

Tabel 4 Perhitungan Energi

\begin{tabular}{|c|c|c|c|}
\hline $\begin{array}{c}\text { Energi } \\
\text { Teoritis } \\
(\mathrm{kWh})\end{array}$ & $\begin{array}{c}\text { Tahun Basah } \\
\left(\mathrm{Q}_{32}\right)\end{array}$ & $\begin{array}{c}\text { Tahun } \\
\text { Normal } \\
\left(\mathrm{Q}_{56}\right)\end{array}$ & $\begin{array}{c}\text { Tahun } \\
\text { Kering } \\
\left(\mathrm{Q}_{80}\right)\end{array}$ \\
\cline { 2 - 4 } & $21.681 .469,97$ & $8.167 .878,92$ & $59.211,41$ \\
\hline
\end{tabular}

Sumber : Hasil Perhitungan

\section{KESIMPULAN}

Dalam perhitungan potensi debit andalan, PLTMH Kanzy I pada tahun basah $\left(\mathrm{Q}_{32}\right)$ sebesar $22,75 \mathrm{~m} 3 / \mathrm{dt}$, pada tahun normal $\left(\mathrm{Q}_{56}\right)$ sebesar 4,63 m3/dt dan pada tahun kering $\left(\mathrm{Q}_{80}\right)$ sebesar $0,022 \mathrm{~m} 3 / \mathrm{dt}$. Besarnya daya listrik yang dihasilkan oleh PLTMH Kanzy I pada tahun basah $\left(\mathrm{Q}_{32}\right)$ energi yang dihasilkan sebesar 21.681.469,97 kWh. Pada tahun normal atau cukup $\left(\mathrm{Q}_{56}\right)$ energi yang dihasilkan sebesar 8.167.878,92 kWh. sedangkan Pada tahun kering $\left(\mathrm{Q}_{8} 0\right)$ energi yang dihasilkan sebesar 59.211,41 $\mathrm{kWh}$.
Selain itu pada sisi lingkungan debit ekologinya juga tetap terjaga pada saat turbin beroperasi maupun tidak beroperasi, sehingga keberlangsungan biota pada sungai serta obyek wisata air terjun Gunung Baung tetap dapat dilestarikan.

\section{SARAN}

1 Mengingat tingkat kebutuhan konsumsi listrik di wilayah Provinsi Jawa Timur maka perlu segera direalisasikan pembangunan PLTM Kanzy 1 sebagai salah satu usaha optimalisasi sumber daya air yang melimpah di Jawa Timur untuk pembangkit listrik tenaga air.

2 Untuk kajian selanjutnya dapat menambahkan aspek skema pipa sebagai variable optimasi pada pembangkit listrik tenaga mikrohidro Kanzy I.

\section{DAFTAR PUSTAKA}

Anonim. 2014. Laporan Akuntabilitas Kinerja Instansi Pemerintah : Kementerian ESDM.

Anonim. 2007. Pedoman Teknis dan Bangunan Sipil : Kementerian PUPR.

Dandekar, MM dan Sharma,KN. 1991. Pembangkit Listrik Tenaga Air, Jakarta : Penerbit Universitas Indonesia.

Linsey, Ray K Franzini, Joseph B. 1985. Teknik Sumber Daya Air Jilid 1. Jakarta : Erlangga.

Soemarto, C.D. 1999, Hidrologi Teknik, Jakarta : Erlangga. 